\title{
THE EFFECT OF CORRECTIVE SURGERY OF SCOLIOSIS ON CERVICAL LORDOTIC AXIS
}

\author{
EFEITO DA CIRURGIA CORRETIVA DE ESCOLIOSE SOBRE O EIXO LORDÓTICO CERVICAL \\ EFECTO DE LA CIRUGÍA CORRECTIVA DE LA ESCOLIOSIS SOBRE EL EJE LORDÓTICO \\ CERVICAL
}

\begin{abstract}
Aldo Calado ${ }^{1,2}$, Juliano Rodrigues dos Santos ${ }^{1,2}$, Jose Alexandre Cunha Baptista ${ }^{1,2}$, Antonio Carlos Monteiro Braconi ${ }^{1,2}$,
\end{abstract} Guilherme Galito Henriques ${ }^{1}$, Danusa de Melo Rozindo ${ }^{1,2}$, Jefferson Soares Leal ${ }^{2}$

1. Vitoria Apart Hospital, Instituto de Ortopedia eTraumatologia, Serra, ES, Brazil.

2. Hospital Infantil Nossa Senhora da Glória, Vitória, ES, Brazil

\begin{abstract}
Objectives: To quantify the changes in cervical sagittal alignment of patients with adolescent idiopathic scoliosis (AIS) who underwent surgical treatment. Methods: Retrospective study of radiographic data analysis. Data were collected from 25 radiographs of patients with AIS, and 18 cases were included. The mean age was 15.2 years (13-17 years); all subjects were female, operated from March 2010 to October 2015. Pre and postoperatively, cervical lordosis (C2-C7), thoracic kyphosis (T5-T12) and lumbar lordosis (L1-S1) were measured. Scoliotic curves were analyzed and measured in anterior posterior views by the Cobb method and classified according to the Lenke classification. Results: Eighteen adolescent patients were evaluated with a mean follow-up of 31.3 months. There was a negative correlation (-0.613) between post-surgical and pre-surgical cervical lordosis variation, that is, the largest the angulations obtained, on average, the greatest the reductions. Thus, the correlation becomes positive when compared to postoperative period (0.579). Conclusion: We concluded that the correction of adolescent idiopathic scoliosis did not bring about statistically significant changes in the cervical spine, with respect to angle values. Lordotic cervical curves with greater angular value showed a greater variation in the postoperative period, resulting in a better biomechanical balance.
\end{abstract}

Keywords: Scoliosis; Kyphosis; Spine.

\section{RESUMO}

Objetivo: Quantificar as alterações do alinhamento sagital cervical de pacientes com escoliose idiopática do adolescente (EIA) que foram submetidos ao tratamento cirúrgico. Métodos: Estudo retrospectivo, de análise de dados radiográficos. Foram levantados dados de 25 radiografias de pacientes com EIA, e 18 casos foram incluídos. A média de idade foi 15,2 anos (13 a 17 anos), todos os indivíduos eram do sexo feminino, operados no período de março 2010 a outubro de 2015. No pré e pós-operatório, foram medidas lordose cervical (C2-C7), cifose torácica (T5-T12) e lordose lombar (L1-S1). Nas incidências anteroposteriores foram analisadas as curvas escolióticas, medidas segundo o método de Cobb e classificadas segundo a classificação de Lenke. Resultados: Dezoito pacientes adolescentes foram avaliadas com seguimento médio de 31,3 meses. Notou-se correlação negativa $(-0,613)$ entre a variação da lordose cervical pós e pré-cirúrgica, ou seja, as angulações maiores obtiveram, em média, maiores reduções. Dessa forma, a correlação torna-se positiva quando comparada ao pós-operatório (0,579). Conclusão: Concluímos que a correção da escoliose idiopática do adolescente não trouxe mudanças estatisticamente significativas na coluna cervical, no que concerne a valores angulares. As curvas lordóticas cervicais de maior valor angular demonstraram maior variação no pós-operatório, resultando em melhor equilíbrio biomecânico.

Descritores: Escoliose; Cifose; Coluna vertebral.

\section{RESUMEN}

Objetivos: Cuantificar los cambios en la alineación sagital cervical en pacientes con escoliosis idiopática del adolescente (EIA) sometidos a tratamiento quirúrgico. Métodos: Estudio retrospectivo de los datos de análisis radiográficos. Se recogieron datos de 25 radiografías de pacientes con EIA, y se incluyeron 18 casos. La edad promedio fue de 15,2 años (13 a 17), todos los sujetos eran mujeres, operados desde marzo de 2010 hasta octubre de 2015. En el período pre y postoperatorio, se midieron lordosis cervical (C2- C7), cifosis torácica (T5-T12) y lordosis lumbar (L1-S1). En las vistas anteroposteriores se analizaron las curvas de la escoliosis, medidas por el método de Cobb y clasificadas por la clasificación de Lenke. Resultados: Fueron evaluados dieciocho pacientes adolescentes, con un seguimiento promedio de 31,3 meses. Se observó correlación negativa (-0.613) entre la variación de lordosis cervical pre y posquirúrgica, es decir, cuando mayores los ángulos cervicales obtenidos, como promedio, mayores fueron las reducciones. Por lo tanto, la correlación se vuelve positiva en comparación con el postoperatorio (0.579). Conclusión: Se concluyó que la corrección de escoliosis idiopática del adolescente no trajo cambios estadísticamente significativos en la columna cervical, con respecto a los valores de los ángulos. Las curvas lordóticas cervicales con mayor valor angular mostraron una mayor variación en el postoperatorio, resultando en un mejor equilibrio biomecánico.

Descriptores: Escoliosis; Cifosis; Columna vertebral.

Study conducted at the Vitoria Apart Hospital, Instituto de Ortopedia eTraumatologia, Serra, ES, Brazil.

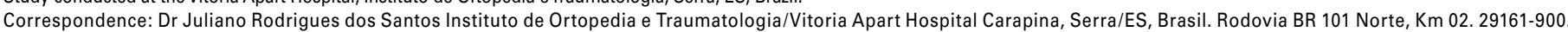
julianocoluna@gmail.com 


\section{INTRODUCTION}

The objectives of the surgical treatment of adolescent idiopathic scoliosis (AIS) are to prevent the progression of the curve, to correct the three-dimensional deformity, and to restore coronal and sagittal balance. For many years, only restoration of coronal balance was possible. The advent of new techniques and technological innovations in implants made correction in more than one plane possible and gave rise to a new concept focusing on deformities from a threedimensional perspective.

Historically, the loss of sagittal balance has played an important role in the pathogenesis of AIS. Dickson confirmed that a loss of thoracic kyphosis can precede the development of deformity and vertebral rotation. ${ }^{1}$ Winter and Nash reported that thoracic hypokyphosis was responsible for reduced lung function in patients diagnosed with AIS. $^{2,3}$ These data emphasize the importance of three-dimensional studies of AIS, even if maximum correction in the coronal plane is sacrificed to achieve this goal.

Long-term studies have documented consequences such as complaints of low back pain, degenerative disc disease, and difficulty in maintaining upright posture. Weinstein et al. ${ }^{4}$ found an incidence of low back pain in $77 \%$ of 50 -year old adults with untreated scoliosis, as compared to $37 \%$ in the control group.

The cervical spine is little mentioned in AIS surgical outcomes. Canavese et al. ${ }^{5}$ showed that scoliotic thoracic hypokyphosis is associated with lordosis rectification or even cervical kyphosis, with evidence of degenerative cervical changes following surgical treatment. These changes were also found following surgical treatment, with an incidence of late postoperative cervical pain of between 17 and $57 \%$. ${ }^{6-8}$

In a recent retrospective study, Lee et al. ${ }^{9}$ evaluated the influence of surgical restoration of cervical lordosis on thoracic kyphosis and demonstrated an important biomechanical relationship between the cervical and thoracic curves, indicating the existence of exclusively thoracic compensatory mechanisms that minimize the poor alignment of the head that results from a loss of cervical lordosis.

The objective of this study is to quantify the changes in sagittal cervical alignment in patients with AIS who underwent surgical treatment.

\section{MATERIALS AND METHODS}

This was a retrospective study that evaluated imaging examinations and medical records. With protocol number 038331/2016, It was approved by the Institutional Review Board.

A total of 29 patients from March, 2010, to October, 2015, duly followed-up in a single spine service, were submitted to inclusion and exclusion criteria and reviewed retrospectively. The inclusion criteria were (1) patients with idiopathic scoliosis submitted to posterior multisegmental instrumentation, (2) the absence of neurological deficits, (3) the absence of previous spine surgery, and (4) the absence of spondylolisthesis. The exclusion criteria were poor radiographical quality for the correct measurement of the vertebral parameters.

All the patients were operated on in the ventral decubitus position. The derotation maneuver was used in all patients. Distraction was applied to the concavity, with compression on the convex side. The rods were molded to restore thoracic kyphosis and lumbar lordosis.

The demographic data collected were age and sex. The radiographic measurements used were the angles of thoracic kyphosis and lumbar lordosis. The angles were measured using the Cobb method..$^{10}$ Cervical sagittal alignment was measured from the lower edge of $\mathrm{C} 2$ to the lower edge of C6. Thoracic sagittal alignment was measured between the upper edge of T5 and the lower edge of T12. Finally, lumbar lordosis was measured between the upper plateau of L1 and the upper plateau of S1. In the anterior-posterior views, the scoliotic curves were measured and classified using the criteria of Lenke et al. ${ }^{11}$

Two examiners retrospectively evaluated the pre- and postoperative radiographs. The radiographs were taken in the prone position, in two views (anterior-posterior and lateral) using 30x90 cm film.

The analysis of the frequency distribution of the categorical variables and the analysis of the central tendency measurements for the continuous variables were conducted to define the profile of the study participants. The Wilcoxon test was used to compare the pre- and postoperative measurements. Verifications of the type of distribution (Gaussian or non-Gaussian) and of the homogeneity of the variances were performed using the Shapiro-Wilk and Levene tests, respectively.

An analysis was conducted to verify the association between the selected variables and the variation in cervical lordosis in the postoperative period. The raw measurement of the estimated association was performed with a confidence interval $(\mathrm{Cl})$ of $95 \%$ and a significance level of 0.05 .

\section{RESULTS}

Eighteen adolescent patients, all female, between the ages of 13 and 17 years (with an average age of 15.2 years of age) were evaluated. The average follow-up was 31.3 months, with a standard deviation of 16.8 months.

The radiographical evaluations of the angle measurements of cervical lordosis, thoracic kyphosis, and lumbar lordosis of each case are displayed in Table 1 and the average angles are displayed in Table 2.

According to the Lenke classification, 10 of the patients had curve type 1 (55.6\%). None of the patients had type 2 or 4 curves. (Figure 1 )

When the pre- and postoperative cervical lordosis and thoracic kyphosis angle measurements were compared, we noted a reduction in the variability of the measurements following surgical intervention, especially in relation to thoracic kyphosis, when we observed the narrowing of the limits in the graphs, demonstrating a direct relationship between the changes in the thoracic and cervical curves. (Figure 2)

From the dispersion of the measurements evaluated compared to each other and to their changes in angulation following surgery, an inversion of the slope of the line for the changes in the measured angles of cervical lordosis, as compared to their measurements before and after surgery was observed. The same was observed with thoracic kyphosis, for the measurement itself. (Figure 3)

The inversion of the relationship of change observed following surgery with the pre- and postoperative measurements is verified by the Pearson correlation presented between them. A negative correlation (-0.613) exists between the change in cervical lordosis observed before and after surgery $(p<0.01)$. That is, the greater the angle obtained, on average, the greater the reduction. Thus, the correlation becomes positive as compared to the post-surgery measurement $(0.579 ; p<0.05)$. The same behavior is observed for thoracic kyphosis, having a negative correlation when comparing its pre-surgical change $(-0.817 ; \mathrm{p}<0.01)$ and a positive correlation postsurgery $(0.382 ; p<0.01)$. Moreover, this behavior was not statistically significant in the correlations between cervical lordosis versus the variation in thoracic kyphosis and for measurements of thoracic kyphosis versus the variation in cervical lordosis.

Table 1. Age and angle measurements according to the radiographical evaluation.

\begin{tabular}{c|c|c|c|c|c}
\hline & $\mathbf{N}$ & Minimum & Maximum & Average & $\begin{array}{c}\text { Standard } \\
\text { deviation }\end{array}$ \\
\hline Age & 18 & 13.0 & 17.0 & 15.22 & 1.35 \\
\hline $\begin{array}{c}\text { Cervical lordosis } \\
\text { preop. (c2-c7) }\end{array}$ & 18 & 2.0 & 18.0 & 9.56 & 4.25 \\
\hline $\begin{array}{c}\text { Cervical lordosis } \\
\text { postop. (c2-c7) }\end{array}$ & 18 & 3.0 & 18.0 & 8.72 & 4.11 \\
\hline $\begin{array}{c}\text { Thoracic kyphosis } \\
\text { preop. (t5-t12) }\end{array}$ & 18 & 4.0 & 50.0 & 24.11 & 13.24 \\
\hline $\begin{array}{c}\text { Thoracic kyphosis } \\
\text { postop. (t5-t12) }\end{array}$ & 18 & 5.0 & 33.0 & 21.94 & 8.27 \\
\hline $\begin{array}{c}\text { Lumbar lordosis } \\
\text { preop. (11-s1) }\end{array}$ & 18 & 35.0 & 80.0 & 51.83 & 12.70 \\
\hline $\begin{array}{c}\text { Lumbar lordosis } \\
\text { postop. (11-s1) }\end{array}$ & 18 & 29.0 & 75.0 & 49.83 & 12.08 \\
\hline
\end{tabular}


Table 2. Correlation matrix of the angle measurements and their post-surgical changes.

\begin{tabular}{|c|c|c|c|c|c|c|c|}
\hline & & $\begin{array}{l}\text { Cervical lordosis } \\
\text { preop. (c2-c7) }\end{array}$ & $\begin{array}{l}\text { Cervical lordosis } \\
\text { postop. (c2-c7) }\end{array}$ & $\begin{array}{c}\text { Thoracic } \\
\text { kyphosis preop. } \\
\text { (t5-t12) }\end{array}$ & $\begin{array}{c}\text { Thoracic } \\
\text { kyphosis postop. } \\
\text { (t5-t 12) }\end{array}$ & $\begin{array}{c}\text { Change in } \\
\text { cervical lordosis }\end{array}$ & $\begin{array}{c}\text { Change in } \\
\text { thoracic kyphosis }\end{array}$ \\
\hline $\begin{array}{c}\text { Cervical lordosis } \\
\text { preop. (c2-c7) }\end{array}$ & Correlation & 1 & 0.289 & $0.484^{*}$ & 0.076 & $-0.613^{* *}$ & -0.414 \\
\hline \multirow{2}{*}{$\begin{array}{c}\text { Cervical lordosis } \\
\text { postop. (c2-c7) }\end{array}$} & Correlation & 0.289 & 1 & 0.074 & 0.231 & $0.579 *$ & 0.067 \\
\hline & P-value & 0.245 & - & 0.770 & 0.356 & 0.012 & 0.793 \\
\hline $\begin{array}{c}\text { Thoracic kyphosis } \\
\text { preop. (t5-t12) }\end{array}$ & Correlation & $0.484^{*}$ & 0.074 & 1 & 0.221 & -0.351 & $-0.817^{* *}$ \\
\hline $\begin{array}{c}\text { Thoracic kyphosis } \\
\text { postop. }(\mathrm{t} 5-\mathrm{t} 12)\end{array}$ & P-value & 0.763 & 0.356 & 0.377 & - & 0.619 & 0.118 \\
\hline \multirow{2}{*}{$\begin{array}{c}\text { Change in } \\
\text { Cervical lordosis }\end{array}$} & Correlation & $-0.613^{* *}$ & $0.579^{*}$ & -0.351 & 0.126 & 1 & 0.407 \\
\hline & P-value & 0.007 & 0.012 & 0.153 & 0.619 & - & 0.093 \\
\hline \multirow{2}{*}{$\begin{array}{c}\text { Change in } \\
\text { Thoracic kyphosis }\end{array}$} & Correlation & -0.414 & 0.067 & $-0.817 * *$ & 0.382 & 0.407 & 1 \\
\hline & $P$-value & 0.088 & 0.793 & 0.000 & 0.118 & 0.093 & - \\
\hline
\end{tabular}

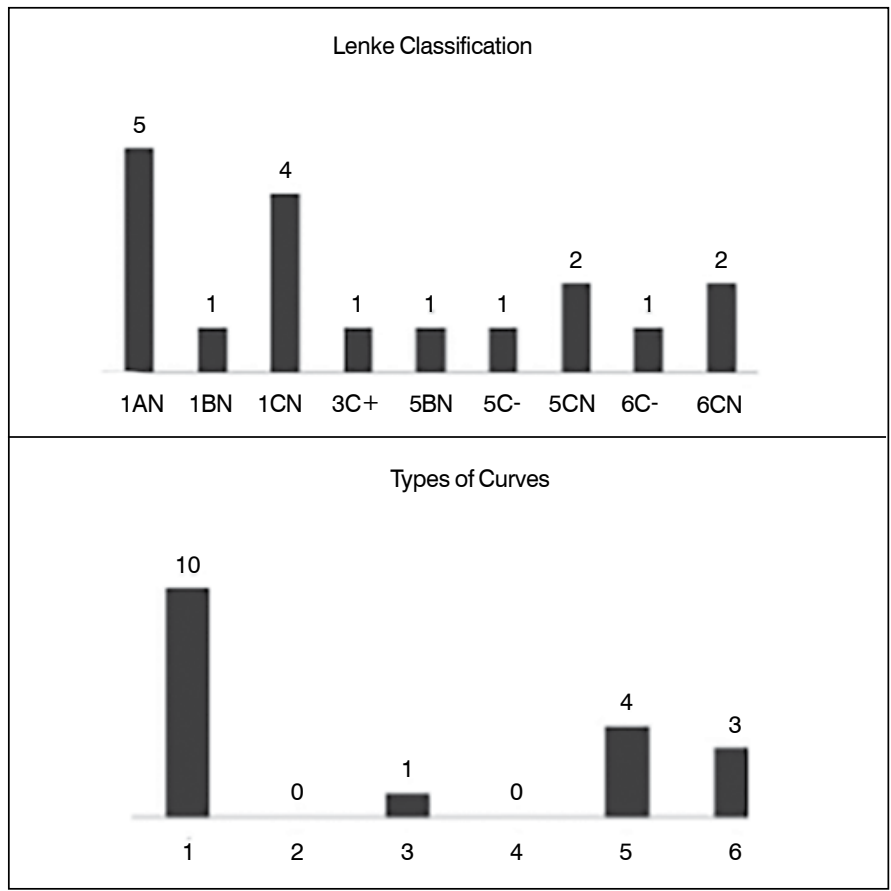

Figure 1. Lenke classification distributed among the patients.

\section{DISCUSSION}

In our study, the effect of surgery on the angular measurements of the sagittal curves of the spine showed that there was no statistically significant correlation between the pre- and postoperative curves. However, in observing the pre- and postoperative changes in cervical Iordosis, we noted that the cervical curves with the greater angular values obtained greater variations following correction of the scoliosis. Thus, it is speculated that the greater the cervical lordosis prior to surgery, the greater its capacity to aid the compensation of the thoracic curves. Therefore, these patients may have a tendency to acquire more spinal stability with less mechanical force. This can have an impact on the clinical outcomes in terms of mechanical overload on the joints, which remain with mobility intact, but this can only be concluded through the long-term follow-up of these patients.

As demonstrated by Kim et al. ${ }^{12}$ the main concern with the lack or insufficiency of the correction of thoracic kyphosis is the increased risk of proximal junctional kyphosis. Previous studies have demonstrated the limitations of the materials for improving hypokyphotic curves, especially in constructions with pedicle screws and hooks. Lowenstein et al. ${ }^{13}$ showed that correction of the thoracic spine with pedicle screws led to a worsening of thoracic kyphosis, having obtained better results in this aspect with hybrid

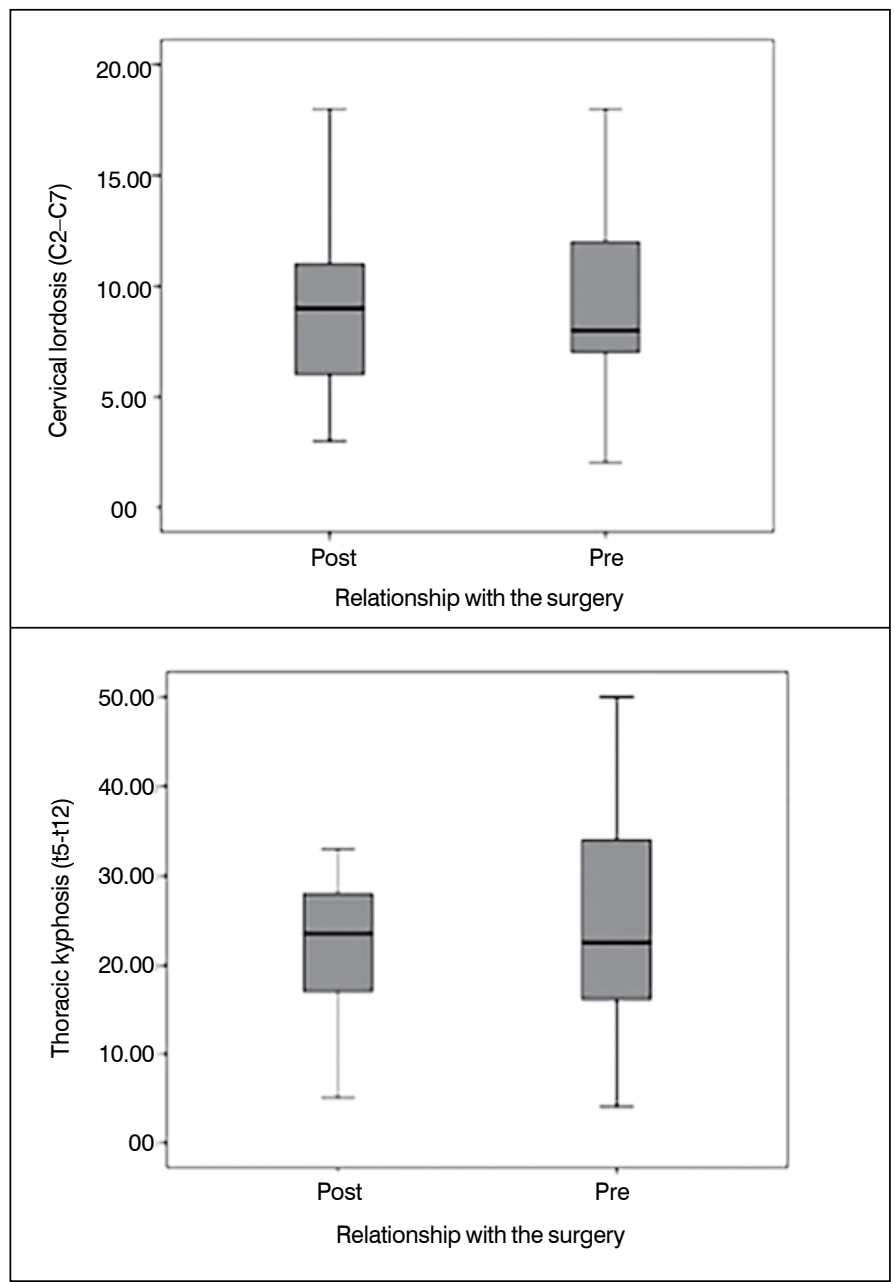

Figure 2. Distribution of the post- and preoperative angle measurements.

constructions. Vorá et al. ${ }^{14}$ observed that fixations with pedicle screws in Lenke $1 \mathrm{~A}$ curves produced lordotizing effects.

In our observations, even though the surgery did not significantly modify the cervical curve, there was a higher capacity for adaptation in the most lordotic patients, which could result in a lower incidence of junctional kyphosis due to the probable better distribution of mechanical loads. Our study did not identify this complication during the average follow-up (31.3 months).

Yann et al. ${ }^{15}$ performed a pre- and postoperative radiographic analysis of 52 patients who underwent surgical treatment for thoracic scoliosis, with an average follow-up of 8 years, aimed at analyzing the effect of surgical correction on the relationship between cervical and 


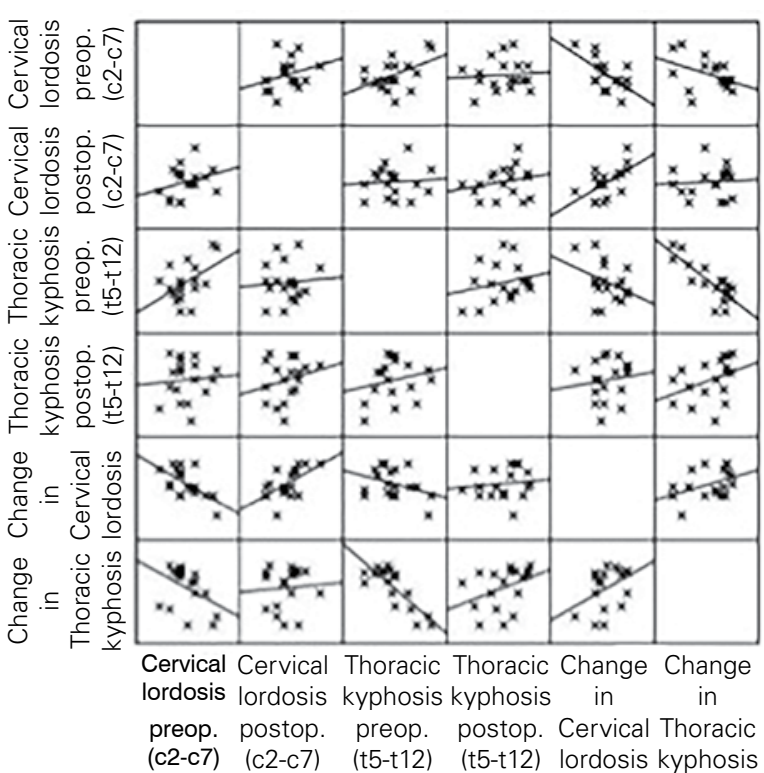

Figure 3. Dispersion matrix of the measurements and angle changes.

thoracolumbar alignment. They concluded that the lumbar lordosis remaining following surgery influenced the cervical lordosis and there was a statistically significant correlation between thoracic kyphosis and cervical lordosis, just as in our study. This correlation was found when they evaluated the proximal portion of the thoracic spine alone - the T1 slope significantly influenced cervical lordosis.

On the other hand, several authors have reported a worsening of the cervical sagittal alignment following correction of the thoracolumbar curves, demonstrating the importance of the relationship between these curves in the postoperative period. ${ }^{5,16}$

These studies have limitations: the number of cases in our study, while not insufficient, is a factor that limits a more comprehensive evaluation. Secondly, the variety of curves operated on, that is, the heterogeneity of the curves in the same sample is a limitation. Certainly, selecting only cases submitted to thoracic spine arthrodesis would create a standard for an analysis with fewer variants. Thirdly, largescale multicenter studies could offer more comprehensive research on the evaluation of the effect of the surgical treatment of scoliosis on cervical lordosis.

\section{CONCLUSION}

We concluded that the correction of adolescent idiopathic scoliosis did not bring about statistically significant changes to the cervical spine, in terms of the angular values. The higher-value lordotic curves demonstrate greater postoperative variation, better supporting biomechanical balance, following the correction of the scoliosis.

All the authors declare that there are no potential conflicts of interest regarding this article.

CONTRIBUTIONS OF THE AUTHORS: Each author made significant individual contributions to the development of the manuscript. JRS and AC were the main contributors to the writing of the manuscript. JACB, ACMB, GGH, and AC performed the surgical procedures, conducted the outpatient follow-up of the patients, and collected the clinical data. JRS, AC, and JACB evaluated the statistical analysis data. JRS, AC, and JACB conducted the bibliographical research. JRS and AC reviewed the manuscript and contributed to the intellectual concept of the study. DMR data collection and bibliographic review. JSL methodology planning, data collection and article revision

\section{REFERENCES}

1. Dickson RA. The etiology and pathogenesis of idiopathic scoliosis. Acta Orthop Belg. 1992:58(Suppl 1):21-5.

2. Winter RB, Lovell WW, Moe JH. Excessive thoracic lordosis and loss of pulmonary function in patients with idiopathic scoliosis. J Bone Joint Surg Am. 1975;57(7):972-7.

3. Lin $\mathrm{HY}$, Nash $\mathrm{CL}$, Herndon $\mathrm{CH}$, Andersen NB. The effect of corrective surgery on pulmonary function in scoliosis. J Bone Joint Surg Am. 1974;56(6):1173-9.

4. Weinstein SL, Zavala DC, Ponseti IV. Idiopathic scoliosis: Iong-term follow-up and prognosis in untreated patients. J Bone Joint Surg Am. 1981;63(5):702-12.

5. Canavese F, Turcot K, De Rosa V, de Coulon G, Kaelin A. Cervical spine sagittal alignment variations following posterior spinal fusion and instrumentation for adolescent idiopathic scoliosis. Eur Spine J. 2011;20(7):1141-8.

6. Ofiram E, Garvey TA, Schwender JD, Wroblewski JM, Winter RB. Cervical degenerative changes in idiopathic scoliosis patients who underwent long fusion to the sacrum as adults: incidence, severity, and evolution. J Orthop Traumatol. 2009;10(1):27-30.

7. Edgar MA, Mehta MH. Long-term follow-up of fused and unfused idiopathic scoliosis. J Bone Joint Surg Br. 1988:70(5):712-6.

8. Moskowitz A, Moe JH, Winter RB, Binner H. Long-term follow-up of scoliosis fusion. J Bone Joint Surg Am. 1980;62(3):364-76.

9. Lee $\mathrm{DH}, \mathrm{Ha} \mathrm{JK}$, Chung JH, Hwang CJ, Lee CS, Cho JH. A retrospective study to reveal the effect of surgical correction of cervical kyphosis on thoraco-lumbo-pelvic sagittal alignment. Eur Spine J. 2016;25(7):2286-93.
10. Cobb JR. Scoliosis; quo vadis. J Bone Joint Surg Am. 1958;40-A(3):507-10.

11. Lenke LG, Betz RR, Harms J, Bridwell KH, Clements DH, Lowe TG, et al. Adolescent idiopathic scoliosis: a new classification to determine extent of spinal arthrodesis. J Bone Joint Surg Am. 2001;83-A(8):1169-81.

12. Kim YJ, Lenke LG, Bridwell KH, Kim J, Cho SK, Cheh G, et al. Proximal junctional kyphosis in adolescent idiopathic scoliosis after 3 different types of posterior segmental spinal instrumentation and fusions: incidence and risk factor analysis of 410 cases. Spine (Phila Pa 1976). 2007;32(24):2731-8.

13. Lowenstein JE, Matsumoto $H$, Vitale MG, Weidenbaum M, Gomez JA, Lee FY, et al. Coronal and sagittal plane correction in adolescent idiopathic scoliosis: a comparison between all pedicle screw versus hybrid thoracic hook lumbar screw constructs. Spine (Phila Pa 1976). 2007:32(4):448-52.

14. Vora V, Crawford A, Babekhir N, Boachie-Adjei O, Lenke L, Peskin M, et al. A pedicle screw construct gives an enhanced posterior correction of adolescent idiopathic scoliosis when compared with other constructs: myth or reality. Spine (Phila Pa 1976). 2007:32(17):1869-74.

15. Charles YP, et al. Cervical sagittal alignment in idiopathic scoliosis treated by posterior instrumentation and in situ bending. Spine (Phila Pa 1976). 2015;40(7):E419-27.

16. Hwang SW, Samdani AF, Tantorski M, Cahill P, Nydick J, Fine A, et al. Cervical sagittal plane decompensation after surgery for adolescent idiopathic scoliosis: an effect imparted by postoperative thoracic hypokyphosis. J Neurosurg Spine. 2011;15(5):491-6. 